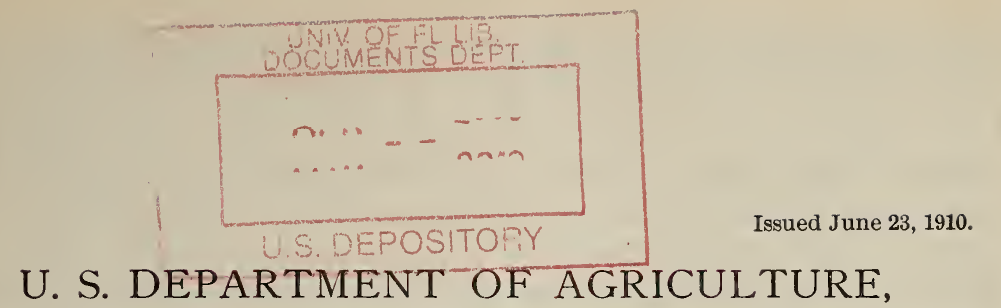

BUREAU OF ANIMAL INDUSTRY.-CIRCULAR 161.

A. D. melvin, Chief of Bureau.

\title{
WHEY BUTTER.
}

By C. F. Doane,

Assistant Dairyman, Dairy Division.

The practicability of making whey butter as a by-product in Cheddar or American cheese factories has hitherto received but little consideration. A few attempts to manufacture whey butter have been made at different times, but apparently not with satisfactory results, and they have generally been given up at the end of the first season. Exception may be made, however, in the case of a company that was organized about two years ago in the State of New York for making whey butter on a plan modeled after the centralizer system. To carry this out a number of cheese factories were equipped with power and separators and the cream was collected by wagon, hauled to a central point, and churned.

For more than a year the Dairy Division has been interested in this subject and it has conducted an experiment under practical conditions. The plant used was a purely local affair, intended to take care of the whey and cream of but one factory. This factory, situated in Wisconsin, received a maximum daily run of 16,700 pounds of milk, which is above the average. In other respects it would be considered a good average factory with a maker who was looking out for the yield of cheese and for the best interests of the factory patrons.

\section{EQUIPMENT OF PLANT.}

The plant which was installed for the work of making the butter proved satisfactory in every way. The factory already had a boiler and a 5-horsepower engine. A gasoline engine would be just as effective. The remainder of the equipment consisted of a tank for whey, capacity 12,000 pounds; a separator, capacity 3,500 pounds per hour; a combined churn and worker, butter capacity 100 pounds; 42929-Cir. 161-10 
and a rotary pump, with a capacity of 4,000 pounds per hour. There were besides a few smaller pieces of apparatus, including a small butter print, butter paddles, a packer, tin pails, and spouting to carry the whey from the cheese vats to the large receiving vat.

A room containing about 250 square feet of floor space is sufficient to hold all the machinery and the receiving tank. This room does not necessarily have to be of the best construction, but the floor should be tight, so that it can be scrubbed without dripping through. In addition to this main making room there should be refrigerator space large enough to hold a small quantity of butter and a large can of cream. A building for storing ice is also needed.

\section{COST OF MACHINERY.}

A second-hand separator was secured for our purpose and made as good as new for $\$ 300$. Other items were: Churn, $\$ 125$; tank, $\$ 45$; pump, $\$ 25$; small items, $\$ 25$; line shaft, pulleys, and labor, $\$ 50$.

The equipment purchased for this factory cost about $\$ 800$. This sum, however, does not represent the total equipment, as the factory already had the room, boiler, and engine. Where room and power are not already available the plant would cost approximately from $\$ 1,000$ to $\$ 1,200$. A portion of this cost should not be charged up wholly against the butter equipment. The engine could be used for operating mechanical agitators, which are labor savers and well worth the cost of installing in large factories, while the ice house and refrigerator could easily be worth their cost as an accommodation to the patrons and the family of the cheesemaker.

THE YIELD OF BUTTER FROM WHEY.

The amount of butter made is calculated on the basis of the amount of milk delivered-so many pounds of butter for each 1,000 pounds of milk. Some extravagant statements have been made in news items in regard to the yield of butter from whey. According to reliable information from the New York company previously mentioned which promoted this industry, the best factory secured an average of 3 pounds of butter to 1,000 pounds of milk delivered. This factory was unusually careful to save every part of the fat possible. The factory in which our experiment was conducted made almost exactly 3 pounds of butter to 1,000 pounds of milk delivered. The yield of butter for different months varies within comparatively wide limits. For June the yield was $2 \frac{1}{2}$ pounds of butter per 1,000 pounds of milk, while for October it was $3 \frac{1}{2}$ pounds. The variation for days is even greater. The yield in a day has fallen as low as 2 pounds and gone as high as 5 pounds of butter to 1,000 pounds of milk. The cheese was made up at this factory in the same way as adopted by most fac-

[Cir. 161] 
tories, and there was nothing in the methods that should increase or decrease the percentage of fat in the whey over or under the average cheese factory.

To secure the maximum yield it is necessary to save the drippings from the milled curd, otherwise a large part of the butterfat would be lost. The writer has noted one instance where there were 58 pounds of whey dripped from the milled curd of a 5,000-pound vat of milk. This tested 11 per cent of fat. In the ordinary way of making cheese an average leakage from the milled curd of a vat of 5,000 pounds of milk would be about 40 pounds, testing about 8 per cent of fat.

SEPARATING THE WHEY.

In most of the Swiss-cheese factories the whey is run into old tanks which are poorly cared for and where it is allowed to stand until the fat has risen to the top. This practice is of course to be condemned. In making whey butter it is the best practice to run the whey directly from the vats to a thoroughly sanitary tank, and it should be separated with as little delay as possible. In a large factory the separators can be started as soon as the first whey is drawn from the vat. It will usually be found necessary to use a pump for elevating the whey from the tank to the separator, in which case a pump that is easily cleaned is very desirable. Where there is much whey to separate a separator with a large capacity should be used. From our work it is apparent that any separator which will skim milk satisfactorily is also good for whey.

\section{CHURNING WHEY CREAM.}

No peculiar difficulties present themselves in churning. Naturally a very small portion of cream is received in proportion to the volume of whey running through the separator, and the cream can be churned as soon as it is separated if so desired. It is believed that from 20 to 30 per cent of starter added improves the flavor. This starter should be milk which has been allowed to sour. The whey cream may be allowed to stand a day before churning and the sour starter can be added the evening before. The starter in all cases should be sour and thick before it is put into the cream, otherwise it would be thickened by the rennet and the resulting curd would hold a large portion of the fat and carry it into the buttermilk.

The cream should be churned at a little lower temperature than cream from milk. The Wisconsin factory where our work was carried on churned below $50^{\circ} \mathrm{F}$. at all times and much of the time at 45 degrees. The cream was churned until the butter granules were the size of a grain of corn, when it was washed with cold water, salted at the rate of 1 ounce of salt to a pound of butter, and worked. 
THE QUALITY OF WHEY BUTTER.

The butter made from whey is good for table use-much better, in fact, than a large part of the butter sold to the retail trade. However, the drippings from the milled curd give the butter a characteristic flavor which is difficult to describe. This flavor brings down the theoretical score somewhat, but does not seem to injure the butter for table use. Were it not for the whey from the milled curd it is probable that an expert could not distinguish whey butter from the best creamery butter, but such a large portion of the fat is in this whey from the milled curd that it would be wasteful not to save it. Whey butter is apparently a little softer than the regular creamery butter, but a number of tests showed that this was not due to excessive moisture.

The butter made in our experimental work was sold partly to patrons of the factory and local dealers, the remainder being shipped to the Chicago market. That sold to the local trade brought a little less than the best creamery butter, while the portion shipped sold for from 2 to 3 cents under the regular price for creamery butter. A few people professed not to like the whey butter, and there was and is considerable prejudice manifested against it, which is absolutely groundless. It is, in fact, very probable that the milk coming to the ordinary cheese factory is purer than the milk delivered to the average creamery in the United States.

The whey butter made in the New York factories has been selling in the eastern markets along with the regular creamery butter. Butter made from whey should be sold as " whey butter," and not simply "s "butter." The butter made in the Wisconsin factory was sold as whey butter.

\section{PROFITS IN MAKING WHEY BUTTER.}

In our experimental work a careful account was kept of the butter made, the price received, and the expenditures. The expenses were as follows:

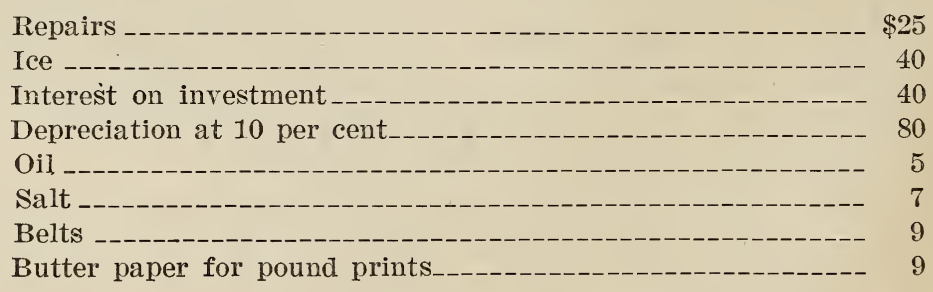

Total

Coal, $1 \frac{1}{4}$ cents per pound of butter made.

Labor, $2 \frac{1}{1}$ cents per pound of butter made. [Cir. 161] 
The cost of repairs, interest, and depreciation would be approximately the same for a factory of any size, while the cost of fuel and labor per pound of butter can be calculated for any other factory. The butter sold at an average of about 20 cents a pound.

A factory with a maximum daily run of 10,000 pounds would receive about $2,000,000$ pounds of milk in a year; this would, on the basis of 3 pounds of butter for each 1,000 pounds of milk, make 6,000 pounds of butter which would have sold, on the basis above mentioned, for $\$ 1,200$. Allowing one-half of the gross income to the farmers, as is the case at the Wisconsin factory, there would remain $\$ 600$. From this must be deducted fixed charges, as calculated above, of $\$ 215$, and the charge for labor and fuel of $3 \frac{1}{2}$ cents a pound on 6,000 pounds, which amounts to $\$ 210$. The total charges would therefore amount to $\$ 425$, and the year's profit for a factory of this size would consequently be $\$ 175$.

There are, however, a number of things to be considered. First, it should be stated that the labor connected with the experimental work was performed by the regular help except for two months, when a man was hired who would probably have been hired any way for one month. In fact, except in factories where the help can barely take care of the milk at the flush of the season, the regular help could handle the extra labor involved in making whey butter, as the work comes when there is not a rush with the cheese. It is probable, also, that the future will see a lessening of the popular prejudice and a greater development of the local market, which would result in better prices being realized by the factories for the butter.

It seems, therefore, that in factories having a maximum run of 10,000 pounds or more, the making of whey butter should be a profitable undertaking for both the factory and the farmer; but factories whose runs are considerably smaller than this would not be justified in undertaking the making of whey butter unless there is some different arrangement made for collecting the cream and churning, or unless the farmers are willing to take less than half the gross returns. Whatever the farmers realize from their whey butter is practically clear gain to them, and if they would take one-third of the gross income, a factory with, say, a maximum daily run of 7,500 pounds could make whey butter at a profit.

As the business is at present established in New York, the farmer, the cheese factory, and the company operating the central churning plant each get one-third of the gross income. The central churning plant furnishes separators to the factories and stands the expense of collecting the cream. The Wisconsin factory, as before stated, gives the farmer one-half. It is, therefore, apparent that the plan adopted in New York is more advantageous to the smaller cheese factories, as the fixed charges and the labor are reduced to a minimum.

[Cir. 161] 
This should be a matter of more than passing interest to farmers who deliver milk to the cheese factories and get the whey in return. There is, of course, considerable feeding value in whey, but, contrary to the opinion of some farmers, the fat contributes but little to this value, as it is present in such a small proportion. In other words, the whey would be nearly if not quite as valuable as a feed after the fat had been removed. If, therefore, this fat can be used to make butter on a profit-sharing basis between the farmer and the factory, there should be little difficulty in arriving at an understanding whereby this waste of a valuable product may be turned into a mutual benefit.

In the factories making Swiss cheese the loss of fat in the whey is comparatively high, and there is always an attempt made to save a portion of it to make butter for domestic use. But the loss of fat in making American cheese has never been considered great enough to warrant any attempt to recover it. As the whey has usually been kept in very insanitary tanks, most of this fat has appeared on the top as a dark, filthy mass that soiled the milk cans and was usually skimmed off and thrown away. Even if allowed to remain in the whey it was, as before stated, of little feeding value.

VALUE OF SKIMMED WHEY AS FEED.

The average composition of cow's milk in the cheese districts where cows are bred for milk instead of butterfat, and the average composition of whey, are about as follows:

Average composition of cow's milk (for cheese making) and whey.

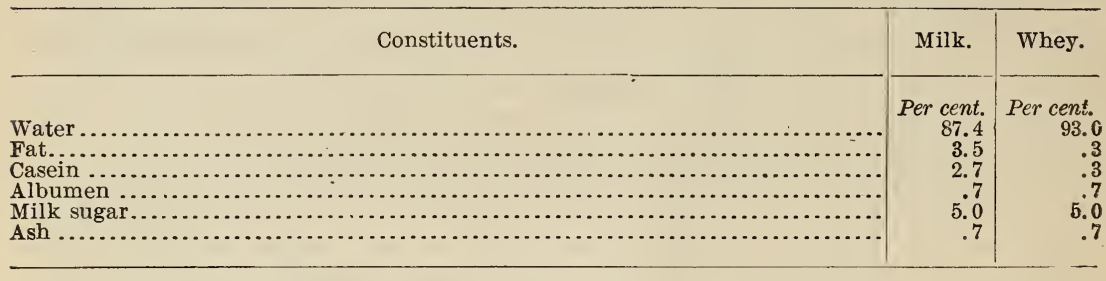

Milk is commonly regarded as a complete food. In the making of cheese most of the casein and fat go to form the cheese, but the other constituents of the milk do not enter into the cheese, except as they are held in suspension or solution in the whey which remains in the cheese. Of this the fat can be seen to be a very small portion. Calculating on the basis of the market value of food constituents, the albumen, being the protein of the whey, would have a cash value five times greater than the fat, and the milk sugar would be worth many times the value of the fat. In view of this the oft-repeated 
objection on the part of the farmer that skimmed whey has no feeding value is erroneous. The removal of the fat, which makes up such a small percentage of the whey, in fact makes no perceptible difference in the value of the whey.

While it is true that the quantity of butterfat in whey is small and may not appear to be worth consideration, when the loss from one factory for a year is considered it amounts to a considerable sum of money. The cheese factory in which the Dairy Division has been interested paid to the farmers about $\$ 1,000$ for their share of the butter in one year, and this sum is of course practically a clear gain to the farmers. In addition to this gain the patrons of the cheese factory can buy the butter at a lower price than they can buy creamery butter shipped in and retailed from local stores.

In view of these facts the writer is decidedly of the opinion that it is to the best interests of the farmer for the cheese factories to make whey butter where the factory receives sufficient milk to warrant the expenditure for necessary space and machinery.

\section{SUMMARY.}

1. Whey butter can be made in American cheese factories at a profit to both factory owner and farmer.

2. In a factory receiving a maximum flow of milk of 10,000 or more pounds a day some profit should be made after giving one-half of the gross returns to the farmer.

3. Very little of the feeding value is removed from the whey in skimming, so that the farmer gets larger returns from the butter sold than when the fat is fed to hogs or calves.

Approved:

JaMres Wilson,

Secretary of Agriculture.

Washington, D. C., April 2, 1910. 


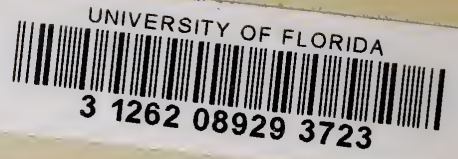

